\title{
Ravens at Play
}

\author{
Deborah BiRd Rose, Stuart CoOKe \\ AND THOM VAN DOOREN \\ MACQUARIE UNIVERSITY AND UNIVERSITY OF \\ NEW SOUTH WALES
}

\section{-DebBie: En ROUTE}

We were driving through Death Valley, an American-Australian and two Aussies, taking the scenic route from Las Vegas to Santa Cruz. Death Valley is part of the Mojave Desert, which extends from Nevada into eastern California. It was March 2009. A few wildflowers were in bloom - mallow and daisies, mainly. The sagebrush had recently finished its brilliant yellow extravaganza. The sagebrush checkerspot butterflies were everywhere; across the open flats, bright orange butterflies caught our eyes and sparked up our engagements with the place. Their lively action gave a vividly charged energy to country whose colours tended toward an austere and striking range of sand, clay, and sage, laced up with patches of green and silver. Thom was driving, and I was glad to be free to be mesmerised.

Miles and miles across the scrubby flats, and always we were surrounded by bleached-out folded mountains, and always something was happening. If not butterflies, more changes in the land. And from time to time, other animals. Two ravens flew low across the scrub to our right, one bumping the other in mid air. We wondered about springtime in the valley, about nests, playful nudges, and lively 
encounters. We were driving, and we were gone before we could do more than glance and speculate.

Then we saw a sign depicting a human hand and a canine mouth. Across this iconography of feeding was the circle and cross-line meaning 'don't'. Were they talking about coyotes or kit foxes? Were there feral dogs? Did they mean only that we ought not to feed them by hand, or were they warning us off sharing food with animals altogether? Very soon we learned that the sign was not generic. The car ahead of us had stopped, and as it moved off we saw that it had been approached by a coyote. Now it was our turn. Truly, there was a coyote strolling down the middle of the road, not at all oblivious to us, but rather quite clearly wanting us to pull up. We stopped, just as the car ahead of us had done. Stuart and I were out on the tarmac with our cameras, and the coyote meandered toward us, looking at us, opening wide his mouth, pausing often for us to take photos. He came close, perhaps a couple of metres from the front of the car. Ears upright, tail held low, body expressing confidence, and his mouth, when not opened wide, was relaxed and unaggressive. Certainly, that gaping mouth could have been a show of aggression, but at the time it spoke 'food' to me. ${ }^{1}$ We all-humans and coyote-kept a careful distance from each other.

The urge to feed him was overwhelming, but our group was not in perfect accord. Stuart was keenly attuned to the longer term consequences of engaging in a relationship we wouldn't be there to sustain. But I longed to leave food for him. I was completely entranced with the opportunity to be so close to a coyote. As a child in Wyoming I'd heard them yike, but I'd never been face-to-face. I wanted to give food as thanks - as an offering to this particular guy, his life choice, his openness to encounter. Stuart said it was horribly irresponsible, and that there would be nothing generous in the gift in the long term. I was torn in my heart, wondering if I was just indulging my own desires, or whether there was an ethics of giving that might be appropriate in this context. Marcel Mauss's The Gift tumbled over Jacques Derrida's 'hospitality' in my desire to come up with a snappy answer to Stuart's certainty.

By then another car had arrived and the 'opportunistic scavenger', as coyotes are known in the technical literature, moved on to stop another group, no doubt going through his repertoire of encounter and address. 
We drove off talking about Donna Haraway's work on encounters in multispecies environments. We were coming from a large impersonal conference and were heading for Santa Cruz to workshop with Haraway, Anna Tsing and their colleagues. Haraway's work was fresh in our minds. She makes the case that the pertinent ethical question concerning humans and animals may be: Are they willing to engage in communication and response, and with what consequences for whom? We were in no doubt that we had been addressed; that we couldn't fully agree on an appropriate response seemed also to be significant. We assumed the coyote was after food because the sign had forewarned us that he might be. We were transients in a material-semiotic field that included the sign, the road, the car, the coyote and the country. It included us, of course, and it included history. My field of encounter included my embodied self: a flesh-of-the-world creature who was aching to make an offering to the shimmering vitality of this brave fellow creature.

I knew that the coyote would be encountered differently by different people. Our goodwill was not going to be shared by all. When I was a child these creatures were called kai-yotes (rhymes with boats), and the term was often full of disrespect. They were held to be sheep-killers, and they were hated. As I learned later, coyotes across North America have been shot, poisoned, baited, snared, trapped and tortured. They've had bounties on their scalps, and in the period 1916 to 2007 six and half million coyotes are known to have been killed. In 2008, ninety thousand were killed. Most of these killings were at the behest of pastoralists. ${ }^{2}$ Although these facts were not foremost in my mind at the time, the inescapable memory was of our recent encounter with a woman back up the road. There were road works, and she was holding a sign telling us to stop. Another sign warned us that we might wait for twenty minutes, so I got out of the car to chat with her. The subject of hunting came up and she told me that her ambition in life was to make a 'duster' for herself out of the skins of coyotes she had shot. ${ }^{3}$

What was this little fellow on the road thinking of? Coyotes must surely know that some humans are killers, just as they must know that most humans don't kill coyotes. This guy seemed to think the area was safe; that in a national park he wouldn't be shot down in cold blood. Even here, though, he might end up coming too close, or biting the hand that was silly enough to be placed close to his mouth. He might pull up a truck carrying folks with guns, and elicit a lethal response from 
rogue humans. Or, he might himself gain the reputation of a rogue and become killable. What I loved was his daring-his bold and confident choice to face down cars and address humans, to initiate encounters in what Haraway calls the contact zone: a region of recognition and response. We knew we were in a rich space. Mary Louise Pratt wrote of the contact zone as a place of transcultural encounter, linking it to travel writing, colonisation, recognition, exchange and the dynamics of power. ${ }^{4}$ James Clifford, another Santa Cruz colleague we hoped to visit, also worked with the term in the context of travel, encounter and power. ${ }^{5}$ Haraway brings contact zone analysis into multispecies domains and poses significant questions of embodied, emplaced becoming: 'Who are you, and so who are we? Here we are, and so what are we to become?'6

Face to face with the coyote, we were encountering a lot of uncertainty, and we left it at that for the moment. We knew that coyotes are trickster and creation beings in some North American Native cosmologies, and we thought the fellow we had met was charmingly, almost irresistibly, clever. His address to us posed tricky questions about response, and we wanted to think more about the encounter and about the entangled lives of humans and coyotes. Before we had much of a chance to do so, however, we were drawn into an encounter with others; with ravens to be precise, fellow tricksters and known associates of coyote in the stories and ecologies of this land.

\section{-Stuart: Play at the Coyote's BuRden Basket}

We were heading north through Death Valley, aiming for the last campground in the park. When we got there it was full. It seemed the only option was to keep going north, where we hoped there'd be a good place to hide the car and camp for the night. We planned to stop at a crater named Waso.

By the time we arrived it was late in the day and threads of sunlight were untangling in the cooling air. Waso was a huge, dark mouth before us. We got out of the car and the blustery wind pushed us off in different directions.

I was walking up around the crater's rim. To my left, its mouth; to my right, crevices ran like black scars all the way down to the valley's floor. I'd been in the car too long and wanted to stretch my legs. The supple earth beneath my feet, I could have been scaling an obsidian sand dune. 
You heard the wind creeping down the valley's throat.

Waso Crater was only two thousand years old, but it was a creation site for the Timbisha Shoshoni known as the Coyote's Burden Basket. According to the sign, it was 'where the people emerged to spread in four directions across the land'. In other words, it was a place where the coyote, the trickiest of creatures, would gather materials so that they might coalesce and find new forms in subsequent creations.

As I scaled further up the edge yet other craters began to reveal themselves. Three, four or even five (I can't remember now) eruptions had thrown up shockwaves of dry soil, which had frozen and promptly proceeded to wear away. Despite those somewhat predictable and, in retrospect, embarrassing moments of sublime and awe that followed, I started to think about how the space had emerged for these moments to take place. Apart from us, the Waso site was almost empty of humans, but it hadn't always been like that. Where were the Timbisha Shoshone? It was, after all, their removal from this country that allowed colonising powers and, later, tourists like us to follow in their tracks. In 1933 the National Parks Service ordered them out as part of the establishment of Death Valley National Monument, ${ }^{7}$ attempting to sever an unimaginably complex set of relationships between humans and the rest of the place. A land richly peopled and spoken was blanketed by federal policy. It is testament to the strength of these relationships that the Shoshone stridently resisted federal exclusion until they received tribal recognition in 1983 and were granted a significant land base in 2000 with the Timbisha Homeland Act. None of this was provided by the information on the park signs, however (we had to go to the Shoshone people's own website to find it).

I looked back: Thom was a tiny scratch in the distance; I didn't know where Debbie had got to. Despite the fun of rambling around like that, the desire to return, sit down and talk about the place was slowly growing. After the indulgence of solitude there was the elastic pull of community. I jogged down a saddle between Waso and one of its smaller cousins.

So, sort of trotting back down the sandy shoulder of the crater ... I'd passed Thom on the way back down and now, somewhere behind me, he was following.

In the distance I noticed another car had been parked next to ours. I couldn't see the owners, but locked inside were two yelping cocker spaniels, thrashing about and shining furry golden in the last sheets of sun. As I neared them I soon realised 
why they were so worked up. Right next to the car, perched on the gutter, were two enormous ravens.

The ravens were still and black as the thickest gravity. They were peaceful as sages, and doing a great job of looking oblivious to the snarling, frothing mess of fur and teeth on the other side of the car window above. It seemed to me that the two dogs would have given anything to break through that glass and commence hot pursuit of the cheeky little critters on the road below! I giggled a little. There was no reason not to.

But in my giggling I guess I'd forgotten myself. I wanted to let the ravens know I appreciated their efforts. I'd been approaching them with all the good will one feels for another who has made him laugh, thinking that perhaps we'd all share in the joke together. Now I was only a few steps from them; the slivers of light on their eyeballs were the only signs managing to escape from their dark masses. I said something to them; there was no response. I took another step closer.

In perfect synchrony, the two ravens hopped one step away. The dogs' ranting went up another level; the ravens had hopped over to the front wheel of the car, and were almost out of the dogs' sight.

I took another step towards them; they both leapt, in a short, scratchy jump, one further step away.

I took yet another step; they leapt further away.

They kept leading me on like this. The space between us never increased, but it never decreased, either. They could have been holding me back with an invisible bargepole.

More step-leaps; now we were nearing the edge of the crater, and the car and the crazy dogs were all behind us. I knew I was being played, and I was entirely caught up in the playing. It was their mystery that kept calling me, their choosing to maintain the distance. Here, the mysterious was imminent and subject-driven; that silence had long since vanished. What might have been a solitary, transcendental sense of the sublime before the enormous gulf of a crater had been distracted and dispersed by the agency of two tricksters. Didn't ravens and coyotes hang out together? The hunter breaking open flesh, leaving remnants for the scavenger; the scavenger lightly stepping around the tracks of the hunter. 
I looked back. I wanted to share this with someone. Thom was coming closer, smiling. Now with an audience, I pressed on. I kept walking slowly towards them; the ravens kept hopping, leaping. I had come to the edge of the crater, and they had hopped themselves over its rim and down towards a sharp drop-off. Wind was rushing up from Waso's dark belly and crashing over my face in cold waves. I saw Thom battling against it. He was right there at the rim when it happened.

They opened their wings. In an instant they shot up with the wind to twist and spiral above us.

The wind bashed and threw itself skywards. It blasted out in fists and churning. But the ravens, directly above us, spiralled quietly before turning, and descending in two clear lines back to their places on the sharp drop-off.

Again, they opened their wings to be lifted off. Up they shot. They danced and glided in the fading penumbra. Again, they banked back towards the crater and descended, graceful as knives, and carefully found their feet on the edge of the cliff. I don't know how many times we were left below while the ravens launched then landed, wrapping themselves in this semantic function of 'Again...'

When Debbie returned from her perch somewhere down on the crater's chest, we climbed back into our car and drove away. For the ravens, however, the game wasn't over: as we drove away from the site they followed us, and kept circling and swooping above our car.

What struck us later as we talked about it was the origin of this 'again', this repetition. Where did it begin? How did I, then Thom, become entangled in the ravens' game? What brought all three of us under the game's umbrella when the ravens began circling above our car as we drove away from the crater? What was striking us was the difficulty of pinpointing a beginning to the event, or a primary actor in it. Thom and I weren't involved with the ravens in a set of one-on-one relationships; the game wasn't simply about us and them. Rather, their play took place within, and in response to, a highly complex material-semiotic field.

There were, of course, the dogs trapped in the car. But the trickery was not produced simply because the ravens excited the dogs, but because the dogs were locked in a car next to the ravens. The ravens' awareness of the strength of steel and glass, in other words, allowed them to stand less than a meter from two large dogs without fearing for their safety. Then there was the loud, angry barking of the dogs, 
surely enough to cause concern for even the largest animal. The ravens didn't move away, but seemed content to remain with that sound until I came along. Were they enjoying it? Were they trying to elicit it?

We have already seen how they responded to the two human actors in this story, who formed other, fleshier elements in this material field. Just as the car's steel and glass provided the ravens with a protective barrier between them and the dogs, their hopping from my advances provided similar protection. At the same time, however, they seemed similarly unfettered by the encroachment of two humans; their determination to remain only the smallest possible distance from us, rather than fly away to another part of the park, suggested not only a daring, but a keen knowledge of human biomechanics (our speed), as well as a confidence in their skills (their ability to escape). It was as if we were taking part in something like a script when, having followed them to the crater's edge, they leapt into the final chapter of the story's material, the wind.

It didn't end there, of course. From the dogs' car to the edge of the crater to the circling above our own car as we drove away, their play had continued. At any time they could have lost interest with us and moved onwards, but they didn't. Thus, another element of their play, its humour, was revealed: something about their encounter with this complex field of dogs and steel and humans and wind must have made the ravens want to continue with their game. And so did we. It seemed wrong to suggest that even the ravens were the primary actors in this playful story. Again, it is difficult to pinpoint exactly where to begin explaining this. There is a sense that with the first sentence of any explanation we are determining the explanation's point of origin. Yet the first sound of the first letter of the first word is itself but a link on an endless chain of affects. In a complex material-semiotic field, a word is like a lightning strike. It doesn't resemble, represent or reproduce the charged field from which it came. It doesn't conform or correspond to it. Rather, it has its own intensity, its own mode of being, which in turn generates further affects. The word is a culmination of charges; it is a playing out or performing of the field's intensity. ${ }^{8}$

Consider the Waso Crater. Two thousand years ago its eruption was the culmination of thousands of molten geological stories from the earth's innards. The intensity of this culmination was then performed in the stories of the coyote's burden basket. There are no beginnings here, because each origin recedes into 
countless other forms. The material field is entangled and complex and punctuated by breathing, vocal rhythms.

Breath, to be sure, is the rhythm of this story. As the wind came rushing up the ribs of the crater to lift the ravens into the air, their subsequent flight led Thom and me to draw, quickly and sharply, on this same air. Our lungs full, what followed was our speech: 'Hey, did you see that?'; 'Isn't it incredible?' Stories are told with the breath of a speaking individual. As the Coyote's Burden Basket initiated those first breaths to tell those first stories, so the wind from the crater's lungs continued to create story. On the day of our visit, the ravens' lines of flight through the crater's breath drew forth our first speech. The Waso creation site, in other words, kept making stories. The lightning strike-that breath of speech-continues through the nerves of a human eye. The flash of light, Brian Massumi tells us, passes 'from an autonomous expression into the content of a body and a life'. ${ }^{9}$

It was because we were attentive to the dangling strands of the ravens' playful narrative, therefore, that we were ourselves able to join in. The dogs' frustration. The invisible barge pole. The event was everything. There was no particular subject before or behind it who drove it forward. It was an autonomous doing. The movements of its actors involved the material field in its entirety. It was non-local, belonging directly to the dynamic relation between a myriad of charged particles. ${ }^{10}$

\section{-THOM: AN ECOLOGY OF PLAY}

We camped a little further up the track, the three of us and our car hidden among the desert dunes for fear the rangers might catch us. The night was much too cold for talk, and the stars, along with the constant flitting presences of what seemed to be tiny bats, occupied most of our attention. In the morning, we drove on to an ancient bristlecone pine forest, camping in sites up at the snow line before heading north the following morning and finally arriving at a log cabin in the Sierra Nevada, surrounded by about a foot of snow, and offering warm showers, an open fire and as much hot chocolate as we could drink. Sorensen's was a benign place: the moose head on the wall in the foyer was a plastic blow-up delight, and the spruce and other trees were decorated with strings of little lights in the shape of pinecones. In front of the fire, we began to think again about what it might mean to play with, and be played by, corvids and, as Debbie kept reminding us, to be addressed by coyotes. 
As throughout so much of our trip, Haraway's recent book, When Species Meet, was at the forefront of our thoughts. The play that is the focus of her discussion is largely between 'groups' of two; her and her sheepdog Cayenne, other humans and dogs, and also a wonderfully inventive relationship between a dog named Safi and a donkey named Wister. She outlines a kind of play in which trust is central. Here, two animals meet and successfully communicate that they are playing. In this way, movements and behaviours from other contexts can be put to use as metacommunication which has the potential to produce playful interactions; the canine 'play bow', for example, communicates that bites and other rough behaviour should not be taken as aggression. ${ }^{11}$ Haraway's thick description shows that this kind of play can only be successful when the partners understand and trust each other. In the context of competing with Cayenne in agility sports, Haraway argues that, when it works, there is a kind of synergy, 'a high of "getting it" together in action'. It is in this way that play can provide an opening in which meanings, rules, possibilities, and ultimately the players themselves, can be remade. 'Play makes an opening. Play proposes.'12

But this was not the kind of play that we took part in at Waso Crater. For these ravens-whom our amateur ornithological skills tell us were Corvus corax-trust between the participants was far less important than those components we have identified as daring, knowledge, skill and humour. Here, play was not about trusting one another, but about daring to be playful with others that one does not really know, and who (in the case of the dogs) may want to eat you. In place of the 'open' in which two or more creatures 'get it' together, this raven play was pervaded by a deep sense of unknowing, of distance and mystery. Something quite profound, we thought, occurred in that space of unknowing.

We had to revisit Gregory Bateson's famous essay on play in order to be reminded that one of the most complex metacommunicative events occurs when the already complex statement 'this is play' is turned into the even more complex question 'is this play?'13 It is the dialectic between the two-question and statement-that turns a bounded unit of metacommunication itself ('this is play') into a game. What fascinated us in the actual encounter was that we didn't need to know, analytically or ethologically, what the precise signals were in order to know that play was being proposed, to make our own responses, and to discover that a 
game emerged. We are not corvid experts, but to us it seems probable that the raven's short jump, or hop, is a metacommunicative play signal. It is a gesture toward flight (in both sense of the term); a movement that is simultaneously large enough to keep a raven out of (immediate) danger, while being small enough to invite a land-bound follower. It is a movement that says: 'this movement denotes flight, and at the same time does not denote flight.' It can be understood as a statement 'this is play'; and at the same time it poses the question 'is this play?' Stuart could have responded with the signal 'this is not play' by charging at the ravens and forcing them to fly away, or by ignoring them altogether. However, he chose to affirm 'this is play', by taking a step and then pausing to see what the ravens would do next. They responded with more play, and Stuart, enjoying himself enormously, did likewise.

In the midst of all this play, it is interesting to recall that raven is no stranger to the space of secrets. In many cultures corvids are thought to have once had white or brightly coloured plumage and perhaps also to have sung melodiously. Some stories tell that as a result of bringing light or fire back to the people, raven was burnt black and lost his/her beautiful voice. ${ }^{14}$ But the glistening blues, purples and greens that shine out from raven wings when they catch the light, just right, remind us of this gift and of raven's past. So it is perhaps not surprising that there is a kind of mystery, a holding apart, when ravens play. It seems that while they often play alongside each other-engaging in creative flight behaviour and the curious and playful exploration of a range of inanimate objects-and even copying one another's playful actions, ravens less often play directly with each other-what ethologists call 'social' play. 15 But the worlds at stake in raven play are richly social nonetheless. At Waso Crater we were drawn into contact, encounter, and the formation of multispecies socialities.

And so, at the same time that we were clearly active participants in a game with ravens, this holding apart helped to create the distinct impression that we were, to some extent, also being 'played'. What marks the difference between being played ('toyed with') and actually playing-in so far as there can be a solid border-is a willingness and an ability to respond playfully to the advances of another. This requires attentiveness to and knowledge of others, even if only to know when we are being invited to play, as well as a skilful learning of the kinds of actions that might or might not be appropriate or safe. A daring not to be in complete control, or 
even to really know the other but to play anyway, is also necessary, as is a sense of humour. With all of this in mind, perhaps the relevant question for multispecies relations is: Can people play? Do people have the skill, daring, humour and willingness to give themselves over to indeterminacy and the joy of encounter?

Perhaps for ravens like those at Waso Crater it doesn't matter too much. They will keep playing whether or not we play back. If some people aren't up to the task, it's likely that they'll just find other, more daring and skilful folks, to occupy their time. Their play is not really about getting to know each other. It is not layered over a static and pre-existing world, but rather penetrates deeply into the entangled becoming of all of those involved. After all, play is not a superfluous activity. The ethologists tell us that there are many different kinds of play, and that they likely evolved independently in mammals and birds. ${ }^{16}$ In their story, as with so much of biology post-Darwin, play has an evolutionary function. In this context, in addition to having fun, play is about learning and adaptation. It is through play that birds (often juveniles) get the hang of their bodies and the wind, developing important skills both to stay alive and often also to more readily take the lives of others when they hunt.

Ravens, soaring on the winds of a place of creation, call out for an attentiveness to these ecological dimensions of play. They remind us that whatever else it is, play also often happens at the intersection of life and death; it cuts deeply into the long co-evolutionary stories and the multispecies communities that today make the Mojave desert the place that it is. As such, play does not only happen within a field of interactions, in an important sense it is also a charge which generates that field and the relationships that comprise it. Here, play is connected to the formation of useful relationships, as well as to adaptability; it is 'important in learning and in the development of behavioral flexibility'. ${ }^{17}$ In this context, it is interesting to note that corvids, and the Common Raven (Corvus corax) in particular, are thought to possess the most complex avian play, at least as recognised by some humans. 'As the raven develops adjustments and flexibility of behavior through play, it has the potential for inhabiting a much greater range of environments than birds whose behavior is less flexible.'18

In the playful hopping of ravens, in the opening of their wings to the updrafts of creation, even in their teasing of dogs locked in a car, a whole world is at stake. All of 
us who might want to play with ravens, or who might simply be played with, are drawn into the action in constitutive ways. But so too are all of those who happen to live with ravens-which, given their adaptability and diversity (especially to 'human disturbed' environments), includes most terrestrial ecosystems.

Adaptability has consequences. The success of ravens has often placed limitations on other folks' lives. There in the Mojave, where we played, ravens' adaptability has had devastating consequences for the threatened desert tortoise (Gopherus agassizii). We first encountered these tortoises several days earlier through a sign in the Valley of Fire state park in Nevada, where we had escaped from the overwhelming cacophony of Las Vegas. Populations of the tortoise are in serious trouble throughout the Mojave for a variety of reasons, including predation, disease and human disturbance of habitat. It is likely, however, that one of those reasons has a sharp beak and black wings. Scientist working with the US Geological Survey estimate that in the past twenty-five years:

common raven populations in the western Mojave Desert have exploded by 1,500 percent ... in response to the constantly replenished food and other resources that human developments have made available to them in an environment otherwise too harsh to support many ravens. ${ }^{19}$

The adaptability and diverse patterns of predation and scavenging open to ravens allows them to take advantage of changing ecosystems, but at the same time allows them to place huge pressures on prey species which can be more readily driven to extinction..$^{20}$ Young desert tortoises, whose shells are still soft, are vulnerable to sharp raven beaks.

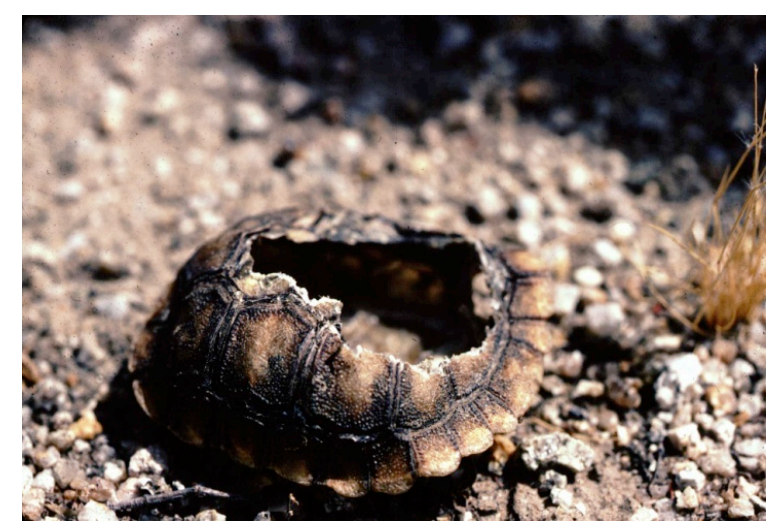

William I. Boarman, Raven-punctured shell of young tortoise ${ }^{21}$ 
In this context, play is connected to a very different kind of 'opening'. Inside the changing ecosystems of the Mojave, the struggling desert tortoise knows that there is more to raven play than innocent fun.

—Debbie, Stuart and Thom: Death in the Valley

We went on to Santa Cruz thinking about death and dispersal. Tortoises have not been the only casualties here. In an effort to reduce their impact on others, the Bureau of Land Management (BLM) has tried continually to limit raven populations in the Western Mojave through both lethal and non-lethal means. Non-lethal methods include reducing raven access to the waste and water resources that have been brought into the region by increased human inhabitation. This situation clearly highlights the anthropogenic nature of this crisis. But poisoning and shooting have also been employed, and they remain components of the BLM's controversial desert tortoise recovery plan. Similarly, coyotes, who have been and continue to be killed en masse, are now the subject of initiatives to protect their lives and to help humans learn to co-exist with them. Such 'search and destroy' methods of inhabiting and managing land are not confined to action for and against animals. Native Americans, too, have experienced histories shockingly similar to those of some of these animals, being by turns despised, dispersed, and subsequently asked to return and become participants in new visions of parks.

The entangled fates of numerous species as they are driven by the twists and turns of anthropogenic action, including the planned and unplanned effects of policy and politics, were at the forefront of our minds; we were planning to offer a seminar in Santa Cruz that would take up some of these issues in the context of extinction. Haraway has written that when we approach the world in awareness of the larger multispecies communities of life, we are pressed to 'cast our lot for some ways of life [and death] and not others'.22 It seemed the perfect opportunity to elicit her views on coyotes, food and play. She was even more vehement than Stuart had been: to offer food would have been to put the coyote at mortal risk. In habituating him to human offerings of food a dangerously unsustainable partnership would have been formed between a human, the human's unreliable distribution of food and the coyote. 
But even if humans are out of the picture, the multispecies possibilities for both food procurement and social interaction that are open to coyotes involve many players and forms of play. Corvids often play with coyotes, as well as with dogs and wolves. The main game is to dive and provoke them to give chase. On other occasions, the birds even chase the canines, or they take turns chasing each other. ${ }^{23}$ Sometimes this is simply done for the fun of it, but other times food is also involved. Ravens and coyotes are symbiotic in their food quest. Adolph Murie writes of his observations: 'They are interested in each others' actions; the raven watches the coyote and the coyote watches the raven. If one has found a source of food he is sure to be joined sooner or later by the other.'24 The ravens' height allows them to warn coyotes of approaching danger. Coyotes' hunting abilities, and ability to open carcasses, benefit ravens. Play, therefore, surely has purposive intent-to communicate the playfulness of the serious work, to engage in metacommuncation by 'performing' mutuality, keeping the compact alive.

In this coming together of corvid and coyote, a curious borderland appears between play that is grounded in on-going relationships of trust (as Haraway has described), and the kind of play between strangers that we took part in at Waso. Perhaps these corvids and coyotes are not exactly performing trust, but rather are testing possibilities of encounter. In asking what role play has in these kinds of life and world making associations, it is difficult and, it seems, unnecessary, to draw hard and fast lines between playing and hunting. Perhaps, in the entangled agendas and motivations that come together when species meet, interactions cannot be organised out into dualised categories that put playing and hunting, or trust and suspicion, at odds with each other. Life and death, play and predation, are all possibilities in an emergent field of uncertainties where events and relationships erupt and are actualised.

Suppose that the coyote who stopped us on the road was proposing a relationship more akin to the one he might share with corvids, one in which we might be both good to play with and good to hunt with, or at least one in which play and food are all mixed up in ways not immediately recognisable to people prone to reducing nonhumans to basic biological drives. Suppose he was willing to test the possibilities of contact, but that he was at the same time suspicious of where our attention might lead. What coyote wouldn't be? But, if we had 'played', if we'd 
offered food, would we have contributed to a human-coyote relationship that sooner or later would end badly for the coyote? Was the best gift we could offer actually a restraint - that we would withhold ourselves, our food, our play? We couldn't play in good faith, because while the game was a transient moment for us, it was a trajectory toward death for him. We remain haunted by this thought: that with coyotes as their lives are now lived in the USA, we can't choose play and choose life at the same time. The question we found so enticing-'can people play?'-now showed a fickle and dangerous side.

Perhaps, in this context, the ethical question is that of taking a stand within our entangled relationships, knowing that there are life and death consequences of our actions. Haraway's description of encounter in the contact zone is incredibly pertinent: 'Who are you, and so who are we? Here we are, and so what are we to become?' We couldn't give an innocent answer to the question of who we were because our personal identities were framed by our species identity. Suddenly, in that moment of encounter and address, we were forced to encounter ourselves as members of a species, other members of which have declared war on coyotes, ravens, tortoises and so many others. What we might become in the contact zone was thus constrained and our becoming moved toward withdrawal: diverse possibilities were both opened up and foreclosed by any kind of play we might choose or be able to engage in with others. The coyote's confident approach, like the ravens' dancing in the air with and beyond us, was another lightning strike-a playing out of conflicted histories of death, dispersal and protection. We were struck, indeed wounded, with a need to turn away, presenting consequences that would crackle with charge far beyond the moment of our passing through a section of a national park. 
Deborah Bird Rose is Professor of Social Inclusion in the Centre for Research on Social Inclusion, Macquarie University, Australia.

Stuart Cooke recently completed a $\mathrm{PhD}$ on Indigenous Australian and Chilean poetics at the Centre for Research on Social Inclusion, Macquarie University, Australia.

Thom van Dooren in a lecturer in environmental studies in the School of History and Philosophy at the University of New South Wales, Australia.

All three authors are members of the ecological humanities group $<$ www.ecologicalhumanities.org $>$.

\section{-NOTES}

1 Philip Lehner, 'Coyote Communication' in Mark Bekoff (ed.), Coyotes: Biology, Behavior, and Management, Academic Press, New York, 1978.

2 Camilla Fox and Christsopher Papouchis, Coyotes in Our Midst: Coexisting with an Adaptable and Resilient Carnivore, Animal Protection Institute, Sacramento,

2005.(http://www.infurmation.com/pdf/CoyoteBook.pdf); Camilla Fox, Living with Coyotes in North America: Challenges and Opportunities, paper presented to the Minding Animals Conference, Newcastle, New South Wales, 13-18 July 2009.

3 'Duster': a long loose-fitting coat.

4 Mary Louise Pratt, Imperial Eyes: Travel Writing and Transculturation, Routledge, London, 1992.

5 James Clifford, Routes: Travel and Translation in the Late Twentieth Century, Harvard University Press, Cambridge, Mass., 1997.

${ }^{6}$ Donna Haraway, When Species Meet, University of Minnesota Press, Minneapolis, 2008, p. 221.

7 Timbisha Shoshone Tribe, 'History of the Timbisha Shoshone Tribe', 2003,

$<$ http://www.timbisha.org/history.htm> (accessed 9 August 2009).

8 Paraphrasing Brian Massumi, 'Introduction: Like a Thought' in Brian Massumi (ed.), A Shock to

Thought: Expression after Deleuze and Guattari, Routledge, London \& New York, 2002, pp. xxiv-xxv.

${ }_{9}$ Massumi, p. xxv.

10 Paraphrasing Massumi, p. xxiv. 
11 Haraway, When Species Meet, p. 240; Marc Bekoff and J.A. Byers, 'A Critical Reanalysis of the Ontogeny and Phylogeny of Mammalian Social and Locomotor Play: An Ethological Hornet's Nest' in K. Immelmann, et al. (eds), Behavioral Development: The Bielefield Interdisciplinary Conference, Cambridge University Press, Cambridge, 1981; Gregory Bateson, Steps to an Ecology of Mind, Granada Publishing, London, 1973.

12 Haraway, When Species Meet, p. 240.

13 Gregory Bateson, Steps to an Ecology of Mind, p. 155.

${ }^{14}$ Boria Sax, Crow, Reaktion Books, London, 2003, pp. 44-5, 83-4, 99-100.

15 Millicent S. Ficken, 'Avian Play', The Auk 94, 1977, p. 578; Bernd Heinrich, Mind of the Raven: Investigations and Adventures with Wolf-Birds, Harper Perennial, New York, 2006, especially pp. 28094.

16 Ficken, p. 580.

17 Joseph C. Ortega, and Marc Bekoff, 'Avian Play: Comparative Evolutionary and Developmental Trends', The Auk 104, 1987, p. 339.

18 Ficken, p. 578.

19 US Geological Survey, 'Scientists Estimate Risk of Raven Predation on Desert Tortoises in the Western Mojave Desert', 2003, <http://www.usgs.gov/newsroom/article.asp?ID=160> (accessed 9 August 2009).

20 US Geological Survey.

21 Image from US Geological Survey, <http://www.werc.usgs.gov/news/2003-09-29b.jpg> (accessed 9 August 2009). Reproduced with permission.

22 Donna Haraway, Modest_Witness@Second_Millenium.FemaleMan@__Meets_OncoMouse ${ }^{\text {TM }}$ :Feminism and Technoscience, Routledge, New York and London, 1997, p. 36.

23 Ficken, p. 577; Sax, p. 26.

${ }^{24}$ Adolph Murie, Fauna of the National Parks of the United States: Ecology of the Coyote in the Yellowstone, Fauna Series no. 4, United States Government Printing Office, Washington DC, 1940, <http://www.nps.gov/history/history/online_books/fauna4/fauna3a.htm> (accessed 9 August 2009). 